\title{
HUBUNGAN MINAT BELAJAR TERHADAP KEMAMPUAN PENALARAN MATEMATIK SISWA SMP PADA MATERI LINGKARAN
}

\author{
Winda Awaliyah ${ }^{1}$, Aflich Yusnita Fitrianna ${ }^{2}$ \\ ${ }^{1,2,3,4}$ IKIP Siliwangi, J1. Terusan Jenderal Sudirman, Cimahi, Jawa Barat, Indonesia \\ ${ }^{1}$ windaawaliyah12@gmail.com, ${ }^{2}$ aflichyf@ikipsiliwangi.ac.id
}

\begin{abstract}
This research aims to determine the relationship of student learning interest to the mathematical reasoning ability of junior high school students in chapter circle. Method used is quantitative with correlation method. this research was conducted in one of junior high school in Cimahi with population of all students of class IX and sample IX-M as many as 30 people. Instrumen used in this research is a questionnaire instrument to measure the level of student learning interest and test instrument to measure the ability mathematical reasoning of students. Analysis results visible there is a significant relationship between student learning interests with the ability of mathematical reasoning and contribution/ influence interest in learning on the ability of mathematical reasoning of junior high school students of class IX is positive is equal to $74,64 \%$ while the remaining $25,36 \%$ influenced by other factors.
\end{abstract}

Keywords: Learning Interest, mathematical reasoning

\begin{abstract}
Abstrak
Penelitian ini bertujuan untuk mengetahui hubungan minat belajar siswa terhadap kemampuan penalaran matematik siswa SMP pada materi lingkaran. Metode yang digunakan adalah kuantitatif dengan metode korelasi. Penelitian ini dilaksanakan disalah satu SMPN di Kota Cimahi dengan populasi seluruh siswa kelas IX dan sampelnya kelas IX-M sebanyak 30 orang. Instrumen yang digunakan dalam penelitian ini yaitu instrumen angket untuk mengukur tingkat minat belajar siswa dan instrumen tes untuk mengukur kemampuan penalaran matematik siswa. Hasil analisis menunjukkan bahwa terdapat hubungan yang signifikan antara minat belajar siswa dengan kemampuan penalaran matematik dan kontribusi/pengaruh minat belajar terhadap kemampuan penalaran matematik siswa SMP kelas IX positif yaitu sebesar $74,64 \%$ sedangkan sisanya $25,36 \%$ dipengaruhi oleh faktor lain.
\end{abstract}

Kata kunci: Minat belajar, Kemampuan Penalaran Matematik

How to cite: Awaliyah, W., \& Fitrianna, A. Y. (2018). Hubungan Minat Belajar terhadap Kemampuan Penalaran Matematik Siswa SMP pada Materi Lingkaran. JPMI - Jurnal Pembelajaran Matematika Inovatif, 1 (2), 93-98.

\section{PENDAHULUAN}

Keberhasilan belajar seseorang dapat dipengaruhi oleh beberapa faktor, baik dari dalam diri maupun dari luar diri, salah satu diantara faktor dalam diri seseorang yang mungkin dapat mempengaruhi hasil belajar adalah minat belajar. Menurut Hidi, Berndoff dan Ainley (Sobandi \& Nurhasanah, 2016) menyatakan bahwa minat memberikan pengaruh positif terhadap pembelajaran akademik, pengetahuan dan bidang studi bagi individu, selain itu minat tidak hanya sebagai pendorong pengetahuan namun juga berperan sebagai faktor pendorong sikap seseorang. Hidi dan Ranninger meyakini bahwa minat dapat mempengaruhi tiga aspek penting dalam pengetahuan seseorang, yaitu perhatian, tujuan dan tingkat pembelajaran. (Sobandi \& Nurhasanah, 2016). 
Pengertian minat belajar dikemukakan oleh beberapa pakar antara lain sebagai berikut: a) Minat menunjukkan kondisi sibuk, rasa suka atau tertarik terhadap sesuatu serta terlibat sepenuhnya dalam suatu kegiatan karena menyadari pentingnya kegiatan tersebut Gie, (Hendriana, Rohaeti, \& Soemarmo, 2017); b) Minat belajar adalah keterlibatan sepenuhnya seseorang dengan cara menuangkan seluruh pikiran dan perhatiannya untuk memperoleh pengetahuan dan mencapai pemahaman tentang pengetahuan yang dituntutnya; c) Minat merupakan rasa ketertarikan, perhatian, keinginan lebih yang dimiliki seseorang terhadap suatu hal, tanpa ada paksaan dari luar. Indikator minat belajar dikemukakan oleh Djamarah, (Hendriana, Rohaeti, \& Soemarmo, 2017), diantaranya adalah: a) Rasa suka atau senang; b) Pernyataan lebih menyukai sesuatu; c) Adanya rasa ketertarikan; d) Adanya kesadaran untuk belajar atas keinginan sendiri tanpa disuruh; e) Berpartisipasi dalam aktifitas belajar serta; f) Bersedia memberikan perhatian.

Penalaran matematik merupakan salah satu dari beberapa kemampuan matematik yang perlu dan penting dimiliki siswa. Pentingnya mempunyai kemampuan penalaran matematik siswa pada dasarnya sejalan dengan visi matematika yaitu untuk memenuhi kebutuhan seseorang di masa yang akan datang. Sejalan dengan itu Soemarmo (Hendriana, Rohaeti, \& Soemarmo, 2017) mengemukakan bahwa pembelajaran matematika diarahkan untuk memberi kesempatan agar dapat mengembangkan kemampuan bernalar, kesadaran akan manfaat dari matematika, menumbuhkan rasa percaya diri seseorang, sikap obyektif dan terbuka untuk mempersiapkan diri menghadapi masa depan yang selalu berubah.

Aspek penalaran sebaiknya menjadi aspek penting yang harus dimiliki oleh seseorang dalam pembelajaran matematika. Penalaran matematika merupakan suatu kebiasaan berpikir yang apabila dikembangkan dengan baik dan konsisten akan membantu serta memudahkan seseorang dalam mengkomunikasikan matematika baik secara tertulis maupun lisan (Hidayat, \& Prabawanto, 2018). Perlu kecermatan dan daya nalar yang baik untuk seseorang agar dapat menuangkan pokok-pokok, gagasan dan ide matematika, karena hal tersebut bukanlah sesuatu yang mudah. Begitu pula ketika menyelesaikan soal-soal matematika terutama bila ingin mendapatkan kesimpulan yang logis dari data dan sumber yang relevan, hal ini harus diikuti dengan kemampuan penalaran yang tinggi (Hidayat, 2017).

Pentingnya mempunyai penalaran matematik juga dikemukakan oleh Baroody dan Nasoetion (Hendriana, Rohaeti, \& Soemarmo, 2017) bahwa penalaran matematik sangat penting dalam membantu individu selain untuk mengingat fakta, aturan dan langkah-langkah penyelesaian masalah, juga dengan menggunakan keterampilan bernalar, seseorang akan melakukan pendugaan atas dasar pengalamannya sehingga orang tersebut akan memperoleh pemahaman konsep matematika yang saling berkaitan dan dapat belajar secara bermakna.

Dalam matematika, penalaran matematik adalah cara berpikir untuk memperoleh kesimpulan matematik berdasarkan fakta atau data, konsep dan metode yang tersedia dan relevan. Pengertian yang sejalan tentang penalaran matematik dikemukakan oleh Kariadinata (2012) yang menyatakan, penalaran dapat diartikan sebagai proses berpikir yang berdasar dari pengamatan indera yang menghasilkan sejumlah konsep dan pengertian. Berdasarkan pengamatan yang sejenis maka akan terbentuk gagasan/ide yang sejenis pula.

Dari beberpa pendapat mengenai pengertian istilah penalaran matematik menurut para penulis dan pakar, Romadhina (Hendriana, Rohaeti, dan Soemarmo, 2017), merinci indikator kemampuan penalaran matematik, diantarnya: a) Mampu mengajukan dugaan terhadap permasalahan yang diberikan; b) Melakukan manipulasi matematika; c) Menarik kesimpulan, menyusun bukti, memberikan alasan atau bukti terhadap kebenaran solusi; d) Menarik 
kesimpulan dari suatu pernyataan; e) Memeriksa kesahihan (kebenaran) argumen dan f) Menemukan pola atau sifat dari gejala matematik untuk membuat generalisasi.

Dilihat dari hasil studi pendahuluan yang dilakukan oleh Awaliyah (2017) yang mempunyai kesimpulan bahwa kemampuan penalaran matematik siswa SMP pada materi lingkaran masih kurang, hal ini disebabkan oleh beberapa faktor. Selain itu dari hasil penelitian yang dilakukan oleh Priatana (Nataliasari, 2014) terhadap siswa SMP Negeri di Kota Bandung menyimpulkan bahwa kualitas penalaran matematis siswa SMP Negeri di Kota Bandung masih rendah atau bisa dikatan belum tercapai sepenuhnya, yaitu hanya sekitar $49 \%$ dari skor ideal. Dari beberapa hasil penelitian diatas, maka dapat diambil kesimpulan bahwa rendahnya kemampuan penalaran matematik siswa disebabkan oleh faktor luar maupun faktor dari dalam diri seseorang, salah satu dari faktor dari dalam diri yaitu minat belajar.

Berdasarkan uraian latar belakang di atas maka rumusan masalah dalam penelitian ini adalah bagaimana hubungan antara minat belajar siswa dengan kemampuan penalaran matematik siswa SMP pada materi lingkaran?. Tujuan dari penelitian ini adalah untuk mengetahui hubungan minat belajar terhadap kemampuan penalaran matematik siswa serta untuk melihat seberapa besar kontribusi minat belajar terhadap kemampuan penalaran matematik siswa SMP pada materi lingkaran.

\section{METODE}

Metode yang digunakan dalam penelitian ini adalah kuantitatif dengan pendekatan korelasi yang bertujuan untuk mengetahui ada tidaknya hubungan serta untuk mengukur seberapa besar kontribusi antara dua variabel (minat belajar dengan kemampuan penalaran matematik). Teknik pengambilan sampel dilakukan secara acak. Penelitian ini dilaksanakan disalah satu SMPN di Kota Cimahi dengan populasi seluruh siswa kelas IX dan sampelnya kelas IX-M sebanyak 30 orang. Adapun instrumen yang digunakan dalam penelitian ini yaitu instrumen angket untuk mengukur tingkat minat belajar siswa dan instrumen tes untuk mengukur kemampuan penalaran matematik siswa. Instrumen angket untuk mengukur minat belajar matematik siswa diadopsi dari Hendriana, Rohaeti, \& Soemarmo (2017). Siswa diminta untuk menjawab dengan memberi tanda centang $(\sqrt{ })$ pada satu pillihan jawaban yang tersedia. Pemberian skor pada tiap pilihan jawaban berpedoman pada skala Likert dengan alternatif jawaban "Sangat Setuju (SS)", "Setuju (S)", "Tidak Setuju (TS)" dan "Sangat Tidak Setuju (STS)". Sedangkan tes untuk mengukur kemampuan penalaran matematik terdiri dari 6 soal uraian kemampuan penalaran matematik dengan materi lingkaran.

\section{HASIL DAN PEMBAHASAN}

\section{Hasil}

Berdasarkan perhitungan pada SPSS diperoleh hasil yang disajikan dalam Tabel 1 sebagai berikut.

Tabel 1. Hasil Uji Normalitas

\begin{tabular}{ccccccc}
\hline & \multicolumn{3}{c}{ Kolmogorov-Smirnov $^{\text {a }}$} & \multicolumn{3}{c}{ Shapiro-Wilk } \\
\cline { 2 - 7 } & Statistic & df & Sig. & Statistic & Df & Sig. \\
\hline Minat Belajar & .154 & 30 & .066 & .950 & 30 & .171 \\
$\begin{array}{c}\text { Kemampuan } \\
\text { Penalaran }\end{array}$ & .123 & 30 & $.200^{*}$ & .953 & 30 & .203 \\
\hline
\end{tabular}


Berdasarkan tabel di atas terlihat bahwa hasil dari sig $>0,05$ hal ini menunjukkan $\mathrm{H}_{\mathrm{o}}$ diterima yang artinya data berdistribusi normal.

Dari hasil perhitungan korelasi dengan rumus $r$ di atas diperoleh $r_{\text {hitung }}=0,864$. Selanjutnya untuk mengetahui apakah terdapat hubungan yang signifikan antara minat belajar terhadap kemampuan penalaran matematik siswa, akan dibandingkan dengan nilai $\mathrm{r}$ tabel dengan menggunakan taraf signifikan 5\% (0,05). Berdasarkan data dari $r$ tabel dengan $d b=n-2=30-2$ $=28$ dan $\alpha=0,05$ diperoleh nilai $r_{\text {tabel }}=0,374$. Karena $r_{\text {hitung }}>r_{\text {tabel }}$ atau $0,864>0,374$ maka $\mathrm{H}_{\mathrm{o}}$ ditolak. Jadi, terdapat hubungan antara minat belajar siswa terhadap kemampuan penalaran matematik. Selain itu, berdasarkan pengujian menunjukkan bahwa hubungannya tergolong sangat kuat.

Selanjutnya dilakukan penentuan besarnya kontribusi/pengaruh (koefisien determinan atau koefisien penentu) minat belajar terhadap kemampuan penalaran matematik. Setelah dilakukan perhitungan KP, diperoleh hasil bahwa besarnya kontribusi/ pengaruh minat belajar terhadap kemampuan penalaran matematik siswa sebesar 74,64\%.

\section{Pembahasan}

Berdasarkan analisis data diperoleh bahwa terdapat hubungan yang signifikan antara minat belajar terhadap kemampuan penalaran matematik siswa SMP kelas IX. Minat belajar memberikan kontribusi sebesar $74,64 \%$ sedangkan sisanya $25,36 \%$ dipengaruhi oleh faktor lain. Hal ini sesuai dengan pendapat Slameto (Siagian, 2013) yang menyatakan bahwa minat adalah suatu rasa lebih suka dan rasa ketertarikan dari dalam diri seseorang terhadap suatu hal atau aktivitas tanpa disuruh. Minat merupakan penerimaan akan suatu hubungan antar diri sendiri dengan sesuatu di luar diri. Minat yang ada dalam diri siswa dapat berkembang tergantung pada seberapa besar keinginan siswa tersebut dalam melakukan aktivitas belajarnya. Minat tersebut dapat meningkat menjadi besar apabila hubungan tersebut semakin kuat atau dekat.

Selain itu, hasil dari penelitian ini sejalan dengan beberapa penelitian terdahulu yang mempunyai kesimpulan bahwa terdapat hubungan positif yang signifikan antara minat belajar dengan hasil belajar matematika, salah satunya yaitu hasil penelitian Sobandi dan Nurhasanah (2016) yang menyatakan bahwa minat belajar berada pada kategori sangat tinggi. Minat belajar sangat berpengaruh positif dan signifikan terhadap hasil belajar, dengan demikian adanya peningkatan minat belajar maka hasil belajarpun akan ikut meningkat. Penelitian lain menyatakan bahwa minat belajar memberikan pengaruh yang sangat besar terhadap hasil belajar sebab dengan minat seseorang akan melakukan sesuatu yang disukai/diminatinya. Sebaliknya tanpa adanya minat seseorang tidak mungkin melakukan sesuatu (Aritonang , 2008).

Dari hasil penelitian dapat disimpulkan bahwa semakin tinggi tingkat minat belajar seseorang maka akan semakin tinggi pula kemampuan penalaran matematik yang dimiliki. Sejalan dengan hal ini kiranya dapat menjadi perhatian lebih terhadap peserta didik, pemerhati khususnya dalam bidang pendidikan matematika pada kemampuan penalaran matematik. Pandangan dari berbagai aspek yang relevan agar dapat juga menjadi pertimbangan dan dasar sebagai upaya peningkatan kemampuan penalaran matematik siswa. 


\section{KESIMPULAN}

Berdasarkan hasil penelitian yang telah dilakukan, maka diperoleh kesimpulan bahwa: (1) Terdapat hubungan yang signifikan antara minat belajar terhadap kemampuan penalaran matematik siswa SMP kelas IX pada materi lingkaran; (2) Kontribusi/pengaruh minat belajar terhadap kemampuan penalaran matematik siswa SMP kelas IX positif yaitu sebesar $74,64 \%$ sedangkan sisanya $25,36 \%$ dipengaruhi oleh faktor lain.

\section{DAFTAR PUSTAKA}

Aritonang, K. T. (2008). Minat dan Motivasi dalam Meningkatkan Hasil Belajar Siswa. Jurnal Pendidikan Penabur. No. 10. 11-21.

Awaliyah, W. (2017). Analisis Kemampuan Penalaran Matematik Siswa SMP pada Materi Lingkaran. Prosiding Seminar Nasional Matematika dan Pendidikan Matematika. Bandung, STKIP Siliwangi,Vol. 5. 991-1000.

Hendriana, Rohaeti, \& Soemarmo (2017). Hard Skills dan Soft Skills Matematik Siswa. Bandung: Refika Aditama.

Hidayat, W. (2017). Adversity Quotient dan Penalaran Kreatif Matematis Siswa SMA dalam Pembelajaran Argument Driven Inquiry pada Materi Turunan Fungsi. KALAMATIKA Jurnal Pendidikan Matematika, 2(1), 15-28.

Hidayat, W., \& Prabawanto, S. (2018, January). Improving students' creative mathematical reasoning ability students through adversity quotient and argument driven inquiry learning. In Journal of Physics: Conference Series (Vol. 948, No. 1, p. 012005). IOP Publishing.

Kariadinata, R. (2012). Menumbuhkan Daya Nalar (Power of Reason) Siswa melalui Pembelajaran Analogi Matematika. Infinity, 1(1).

Nataliasari, I. (2014). Penggunaan Model Pembelajaran Kooperatif Tipe Think Pair Share (TPS) untuk Meningkatkan Kemampuan Penalaran dan Pemecahan Masalah Matematis Siswa MTs. Jurnal Pendidikan dan Keguruan, 1(1).

Siagian, R. E. F. (2013). Pengaruh Minat dan Kebiasaan Belajar Siswa terhadap Prestasi Belajar Matematika. Jurnal Formatif, 2(2): 122-131.

Sobandi, A., \& Nurhasanah, S. (2016). Minat Belajar sebagai Determinan Hasil Belajar Siswa. Jurnal Pendidikan Manajemen Perkantoran, 1(1): 135-142 
